\title{
WIFE ASSAULT, THE JUSTICE SYSTEM AND PROFESSIONAL RESPONSIBILITY
}

\section{DIANA GINN*}

The author reviews the response of the criminal justice system to the problem of wife assault by focusing on the key players within the system. The way the criminal law applies to wife assault affects battered women's access to that area of law known as family law, with negative repercussions for them and their children. Several myths about the nature of wife assault help ensure an inappropriate response. These include the myths that the woman is to blame, that by just leaving the abusive situation she can resolve it, and that if she does not leave it is because she enjoys the abuse.

The author reviews current methods used by police, prosecutors and judges for dealing with wife assault and discusses the inadequacies of those methods. She concludes that despite many recommendations for change, there have been no significant improvements in the way the criminal justice system deals with wife assault. It is incumbent upon the legal profession to demonstrate professional responsibility by ensuring that wife assault is taken more seriously than it is now and than it has been in the past. This is a necessary reform before battered women can rely on the criminal justice system.
L'auteure passe en revue la réaction du système judiciaire criminel dans les cas de violence faite aux femmes en s'attachant aux principaux intervenants au sein du système. La façon dont le droit criminel s'applique à ces cas de violence a une incidence sur l'accès des femmes au domaine de droit appelé udroit de la familley et des répercussions négatives pour elles et leurs enfants. Plusieurs mythes sur la nature de ce type de violence renforcent les réactions inappropriées - le fait que la femme serait coupable, qu'il lui suffirait de partir pour régler le problème et qu'elle doit apprécier sa condition puisqu'elle reste au foyer.

L'auteure examine les méthodes couramment utilisées par la police, le procureur et les juges chargés de ces cas et en relève les diverses insuffisances. Elle conclut que personne n'a réellement tenté de rectifier ces problèmes. Il incombe $\dot{a}$ la profession d'assumer ses responsabilités en veillant à ce que la violence faite aux femmes soit traitée avec plus de sérieux que maintenant et par le passé. Cette réforme est nécessaire pour que les femmes puissent mieux compter sur le système judiciaire criminel.

\section{TABLE OF CONTENTS}

I. INTRODUCTION ...................... 909

II. PRESENT RESPONSE TO WIFE ASSAULT $\ldots \ldots \ldots \ldots \ldots 910$

A. REASONS FOR INEFFECTIVE RESPONSE $\ldots \ldots \ldots \ldots 910$

B. POLICE RESPONSE $\ldots \ldots \ldots \ldots \ldots \ldots \ldots \ldots \ldots \ldots 12$

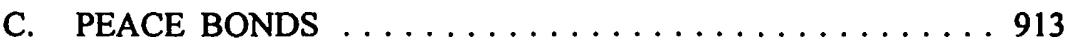

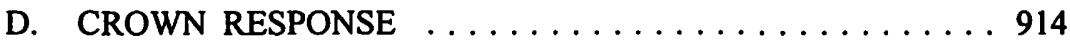

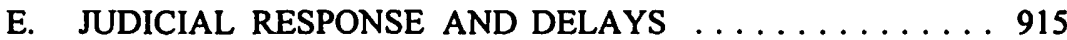

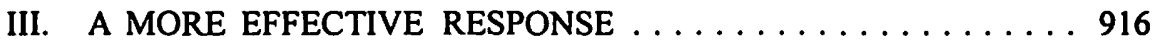

IV. CONCLUSION $\ldots \ldots \ldots \ldots \ldots \ldots \ldots \ldots \ldots \ldots \ldots$ 


\section{INTRODUCTION}

I hope to tie together the theme of this panel - family law - with the themes of the entire conference - violence and professional responsibility - by discussing the way in which the criminal law responds to wife assault.'

I should note that much of my commentary grows out of conversations which I have had with battered women and with those who work with battered women. Before joining the faculty at Dalhousie Law School, I worked with the Nova Scotia Law Reform Commission on a project which examined the legal response in Nova Scotia to wife assault. As part of this project, I held consultations across the province with battered women, shelter workers, police, Crown prosecutors, probation officers and others. While I will also refer to work done by other researchers, my own findings are very much reflected in my comments here.

I will not be focusing on those issues which are generally thought to fall under the heading "family law." I am doing this not only because some of these issues will be dealt with by the other panellist, but also because I see the enforcement of the criminal law in this context as very much a family law matter. The way in which the criminal law is (or is not) enforced will affect relationships within families and may also affect the extent to which, or even whether, a battered woman is able to make use of that body of law generally characterized as family law. ${ }^{2}$

There are many examples of the connection between criminal and family law in this area. For instance, a woman may be hesitant to leave her abusive husband and apply for custody and support if she fears her husband will retaliate with even greater violence. If the law as a whole responded effectively to wife assault, presumably the woman could ask the courts to settle custody and other family law matters, while relying on the enforcement of the criminal law to keep the man from harassing or harming her or the children.

Another example of how an inappropriate enforcement of the criminal law may limit a woman's access to "family law" involves the use of the kidnapping provisions of the

1 I use the term "wife assault" rather than phrases such as "family violence" or "domestic violence" to highlight the fact that in the vast majority of cases, it is women who are experiencing abuse at the hands of their male partners. This is not to deny that violence can also happen in same sex relationships. I have also chosen not to discuss child abuse and elder abuse. This was done for a number of reasons, including time constraints, the fact that at least some of my comments may also be applicable to other kinds of violence within families, and the fact that my own work experience has been in the area of wife assault. Besides my research for the Law Reform Commission of Nova Scotia (elaborated upon infra), over the past fifteen years I have also worked as a relief shift worker with one shelter for battered women in Toronto, sat on the Board of Directors of another Toronto shelter, and been a member of an advisory committee for the shelter for battered women in Yellowknife.

2 Conversely, of course, a battered woman's access to family law protection may affect whether she decides to use the criminal law. Thus, if access to legal aid to settle matters of custody and support is limited or difficult, a woman may be less likely to take steps such as laying criminal charges, which might end the relationship. 
Criminal $\mathrm{Code}^{3}$ to charge women who take their children when they leave abusive partners. I was told of two cases in Nova Scotia. In one, a woman was charged with kidnapping when she left the province with her children to escape her abusive husband. The charge was eventually dropped, but not before the woman was brought back in custody and the children were returned to the father for some time. In the other, a battered woman who brought her children to a shelter was threatened by a police officer with a charge of kidnapping. Because of a strong protest by shelter workers to the Attorney-General's office, the charge was not laid. I am not suggesting that the kidnapping provisions of the Criminal Code are often used in this way; however, only a few such examples will frighten other women into staying in abusive relationships. Certainly, battered women will not make the distinction between family and criminal law; either they will feel that the legal system served them fairly and effectively, or that it did not.

\section{PRESENT RESPONSE TO WIFE ASSAULT}

\section{A. REASONS FOR INEFFECTIVE RESPONSE}

Clearly the present legal response to wife assault is not effective. In recent years, a number of Canadian studies have examined the way in which the criminal justice system deals with wife assault, and all have concluded that there are significant problems. ${ }^{4}$ For the most dramatic proof that the legal system is not managing to reduce the incidence of wife assault, one need only look at the statistics. "Indications are that the criminal justice system has seen gains in public education, but much less success in stopping the violence." ${ }^{.5}$ According to the recent Statistics Canada National Survey on Violence Against Women, "three in ten women in Canada currently or previously married have experienced at least one incident of physical or sexual violence at the hands of a marital partner."6 The same survey found that one third of the women who

$3 \quad$ R.S.C. 1985 , c. C-46, s. 279.

- See The Canadian Panel on Violence Against Women, Changing the Landscape: Ending Violence - Achieving Equality, Executive Summary and National Action Plan (Ottawa: Minister of Supply and Services Canada, 1993) [hereinafter Canadian Panel Executive Summary or Canadian Panel National Action Plan]; The Canadian Panel on Violence Against Women, Changing the Landscape: Ending Violence - Achieving Equality, Final Report (Ottawa: Minister of Supply and Services, 1993) [hereinafter Canadian Panel Final Report]; Cape Breton Transition House, Speaking Out: Voices of Battered Women in Cape Breton 1986-1988, (1988) [unpublished]; Hon. C.R. McQuaid, Inquiry into Police and Department of Justice Policies and Procedures in Cases of Inter-Spousal and Intra-Family Violence (Charlottetown: Island Information Services, 1991); C. Murphy, (Government of Nova Scotia, Department of Community Services), Summary Report: Nova Scotia Crime Victims Needs and Services Research Project (1992) [unpublished]; Tearmann Association for Battered Women, Silence in the Court: Battered Women Talk About Their Experience in the Legal System (1989) [unpublished]; D. Pedlar \& C. Minch, The Domestic Violence Review into the Administration of Justice in Manitoba (Winnipeg: Manitoba Justice, 1991); E.J. Ursel, "Examining Systemic Changes in the Criminal Justice System: The Example of Wife Abuse Policies in Manitoba" (1990) 19 Man. L.J. 529.

5 D. Denham, "Wife Assault and the Criminal Justice System" (1990) 8:2 Vis-a-Vis 1 at 1.

$6 \quad$ K. Rodgers, "Wife Assault: the Findings of a National Survey" (1994) 14:9 Juristat Service

Bulletin of the Canadian Centre for Justice Statistics 1 at 1. 
were assaulted by a partner feared for their lives, ${ }^{7}$ and that weapons were used by nearly half the abusive spouses. ${ }^{8}$

These figures, distressing as they are, fail to highlight the full extent of the violence. The statistics refer to isolated episodes of assault; it is important to remember that for most women, the violence is ongoing and generally escalates over time. Further, the battering is often accompanied by sexual and emotional abuse and enforced isolation. These figures also obscure the fact that different women may be treated quite differently by the legal system, depending on the woman's economic status, race or culture. For instance, as the Canadian Panel on Violence Against Women stated:

\begin{abstract}
Understanding the experience of violence requires understanding the combined impact of gender, race and class.... A woman's exposure to and experience of violence will ... be textured by her socioeconomic position. Access to financial resources will determine the level and the type of support, counselling, legal advice and other survival strategies at a woman's disposal.... When a woman of colour experiences violence she experiences it as a simultaneous attack on both her gender and her race. From experience she knows that anger and hatred directed at both these aspects of her identity are real. When she calls upon systems to respond she cannot trust the response because she knows that she is calling upon systems that do not.understand, value or incorporate her experience either as a woman or as a person of colour.'
\end{abstract}

The fact that the criminal law does not respond effectively to wife assault reflects the myths regarding violence against women which permeate the legal system and society at large.

The first myth is that the woman is actually to blame - she caused the violence by nagging her partner, disobeying him or otherwise asserting her independence. One young woman in Nova Scotia told me that when she called the police after her partner had beaten her, the officer's first question was, "So what did you do to cause it?" Concluding that she was unlikely to receive support or protection, she hung up and is unlikely to call the police again for assistance. Blaming the woman legitimizes violence, reinforces stereotypes regarding appropriate behaviour for women, and both reinforces and refuses to acknowledge the historical imbalance of power between husbands and wives.

The second myth is that the woman could simply end the violence by leaving the home and ending the relationship. This ignores the complex web of emotional, economic and social reasons which explain why it may be extraordinarily difficult to leave. It ignores the fundamental question of why the woman should have to uproot herself and her children, leaving the perpetrator in comfortable possession of the family home. It also ignores the well-documented fact that leaving does not end the violence. 
A woman who leaves or tries to leave an abusive relationship becomes five times more likely to be killed by her partner. ${ }^{10}$

The third, and perhaps most insidious myth, is that if a woman does not leave, or if she leaves and returns, she must enjoy the abuse. A deputy police chief commented to me when I was doing my consultations for the Nova Scotia Law Reform Commission, "You know, if she keeps going back, you gotta figure that she likes it."

Those working within the justice system are often unable to understand the terror and humiliation suffered or to recognize the danger of the situation. Furthermore, the legal environment is itself a hostile and intimidating setting for battered women." The adversarial approach and the experience of being cross-examined can be particularly debilitating for women who have been abused. Women who have been silenced for years are expected suddenly, in a very unfamiliar setting, to present the evidence of their suffering in a manner that the courts find cogent and believable. Without appropriate support services, this can be an insurmountable barrier.

Besides looking at these common themes, it is also useful to look at the various components of the legal system.

\section{B. POLICE RESPONSE}

In recent years, one of the major reforms in police response to wife assault has been the implementation of police directives requiring police officers to lay charges where there are reasonable grounds to believe that an offence has been committed. The reasoning behind these directives is twofold: it may be very difficult for a battered woman to decide, particularly right after an attack, whether or not to lay a charge against her partner; and if the woman decides to lay a charge, she will be blamed by her partner and assaulted again. Therefore, these charging directives are seen as a way of easing the emotional burden and placing the responsibility for the charge on the police rather than on the battered woman. ${ }^{12}$ These directives do not, however, seem to have caused any fundamental shift in police thinking regarding wife assault. In my own meetings with police officers, many expressed resentment that the directives removed their discretion to decide whether a situation was serious enough to warrant

Stated by Dr. P. Jaffe, member of the Canadian Panel on Violence Against Women, during Panel hearings in Halifax, March 1992. In an American study of "interspousal homicide," G. Barnard et al., "Till Death Do Us Part: A Study of Spouse Murder" (1982) 10 Bull. Am. Acad. Psychiatry and L. 271 at 274, it was found that in more than fifty percent of the cases where a woman was killed by her partner, the couple had already separated. D. Berrios \& D. Grady, "Domestic Violence Risk Factors and Outcomes" (1991) 155:2 West. J. Med. 133, reviews files for over two hundred victims of domestic violence who came to the emergency department of a California Hospital. The authors concluded, at 135, that "[p]hysical separation from the batterer ... did not ensure protection for our subjects. Fully a third of the victims in our study were not living with their assailants at the time of the index episode...." See also M.R. Mahoney, "Legal Images of Battered Women: Redefining the Issue of Separation" (1991) 90 Michigan L. Rev. 1. M.L. Fassel, "Wife Assault and the Criminal Justice System" (1990) 8:1 Vis-a-Vis 1.

12 These reasons were cited by both shelter workers and police officers during my consultations for the Nova Scotia Law Reform Commission. 
the laying of charges. However, further discussion suggested that in many cases this discretion would be exercised on the basis of the myths and stereotypes mentioned above. I was told by battered women and shelter workers in Nova Scotia that when police respond to a "domestic" call, the woman is more likely to get help if she is small, pretty, deferential to the police, white and middle class; ${ }^{13}$ if she hasn't tried to defend herself; if she hasn't called the police previously; and if she hasn't "brought the violence on herself" by, for instance, drinking or going out with friends.

Police response to a wife assault raises not only the issue of whether charges should be laid, but also whether the perpetrator should be arrested. In my conversations with battered women, most told me that their partner had not been arrested when the police were called. At most, he might have been taken to the nearest coffee shop, bought a coffee, told not to do it again and then sent home. Where the man was arrested, the women involved felt this resulted more from his attitude towards others than the attack on her; if the husband made the mistake of disturbing the neighbours or being rude to the police, he was much more likely to be arrested than if he had simply brutalized his wife. Obviously, arrest would provide women with immediate protection, in a way that simply laying a charge would not. Section $\mathbf{4 9 5}$ of the Criminal Code deals with arrest powers of the police. Police are not to arrest without a warrant for summary or hybrid offences (the types of charges most often laid in wife assault situations) unless it is necessary to do so for a number of public interest reasons, including the need to prevent the continuation or repetition of the offence or the commission of another offence. Clearly, this may often be the case with wife assault. However, if police are to use this section to arrest batterers, or if courts are to be expected to uphold the arrest by refusing bail, they must be educated ${ }^{14}$ regarding the continued pattern of abuse which makes it exceedingly likely that the offence will recur or be continued.

\section{PEACE BONDS}

Section 810 of the Criminal Code provides that any person who fears that another person will harm her or her children or damage her property may seek a recognizance (peace bond). If the court is satisfied that there are reasonable grounds for the fear, the defendant will be required to enter into a recognizance, promising to keep the peace and be of good behaviour. The court may also attach other conditions. This is different than a criminal charge - the man is simply required to enter into an undertaking with

Canadian Panel Final Report, supra note 4 at 216, "By using their discretionary power, police support or deny access to the justice system for women according to their narrow criterion of the "good witness," that is, white, middle class, able, heterosexual, etc."

While some education regarding the recurring patterns of violence has been undertaken, it does not appear to have been particularly successful; a fairly recent survey of police response to wife assault in Sydney, Nova Scotia states that the police officers "were aware of many of the realities of 'wife battering' that have been documented in recent research" but still felt that the woman should "take a stand and leave." The researcher in this study commented, "Where is the responsibility of men in these situations? As a researcher, I didn't hear police respondents talk about what abusive men should do about their problem as abusers." (Cape Breton Transition House Association, Getting the Message Out: Sydney City Police Address Women Battering (1990) at 17 [unpublished]). 
certain conditions attached. However, a peace bond's effectiveness depends on police enforcement of its terms. I have been told repeatedly by battered women that a peace bond is not worth the paper it is written on. Although breach of a peace bond is a criminal offence, charges are rarely laid. Even if a charge is laid, no immediate protection is offered and the sentence is usually minimal. ${ }^{\text {is }}$ Further, the process for obtaining a peace bond is lengthy, bureaucratic and confusing.

\section{CROWN RESPONSE}

As with police directives, a number of provinces have brought in prosecutorial directives, requiring Crown attorneys to proceed with charges arising out of wife assault unless there are strong public policy reasons for dropping the charges. The rationale for these directives corresponds with one of the reasons for the existence of police directives: if a criminal charge can be dropped at the discretion of a battered woman, the abusive partner may force her to do so. Therefore, requiring Crown prosecutors to proceed is seen as a way of ensuring that these matters go to court and of providing protection for battered women in the interim. ${ }^{16}$ Unfortunately, the prosecutorial directive is sometimes used as a weapon against battered women, forcing them to testify or risk being found in contempt of court. A directive which is used to intimidate women into testifying, particularly where there are no adequate support services, is unlikely to be successful even in achieving the stated aim of protecting a women from continued violence and threats of violence. If a man can no longer beat his partner into dropping the charges, he can now terrorize her into lying or refusing to testify. If she is then threatened with contempt of court, this simply increases her victimization.

As with the police directives, prosecutorial directives do not seem to have brought about significant improvements in the way Crown prosecutors view battered women or in the way they prosecute charges arising from the battering. When interviewing Crown attorneys as part of the Nova Scotia Law Reform Commission's project, I did meet some prosecutors who were very aware of and sympathetic to a battered woman's situation. Unfortunately, they were the exceptions. I was struck by the degree of hostility expressed toward battered women by some prosecutors, who saw them as bad witnesses. I was also struck by how little effort was put into helping them become better witnesses. In addition, due to a combination of factors: a heavy caseload; the fact that wife assault cases are seen as low-profile cases, unlikely to advance one's career; and the fact that at least some prosecutors have a very clear perception of their role and that excludes any aspect of victim support; it was not unusual for the Crown to meet a woman for the first time right before a court hearing. This leaves the woman disoriented and unprepared and means that the Crown is less likely to know the facts

36 For a discussion of the arguments for and against such a policy, see M.F. Rusen, Silencing Their Screams: The Legal System's Response to Male Battering of Women (Ottawa: National Association of Women and the Law, 1992) at 30-36. 
well enough to prosecute effectively and to consult the woman on prosecutorial decisions. ${ }^{17}$ A number of battered women told me that the Crown agreed to reduce the charge without consulting them. The women were intensely frustrated with their lack of involvement in the proceedings and angry that the Crown did not seem fully aware of the dangerousness of the accused.

\section{E. JUDICIAL RESPONSE AND DELAYS}

Criticisms regarding the judging of spousal assault cases generally fall into two categories: judges' attitudes toward women generally and toward wife assault specifically; and the sentencing of batterers. With regard to judicial attitudes, I was told that some judges still tend to blame the battered woman, do not see the need for immediate protection, and do not understand either the extent of emotional and physical violence experienced by the woman or the fact that a court appearance may be an ordeal for her. In a similar vein, the Canadian Panel on Violence Against Women stated: "[w]hen the knowledge of judges is tainted by bias and myths and is marked by an absence of relevant and complete information on crimes of violence against women, the resulting adjudication cannot be fair." ${ }^{18}$

Sentencing is obviously a difficult area for judges. A uniform policy of simply jailing all batterers would not be an effective panacea; ${ }^{19}$ however, there is a sense among battered women and transition house workers, as well as among some Crown prosecutors, police officers and probation officers, that sentences often do not reflect the seriousness of the crime and do not provide any effective protection for the woman. This perception, that sentences for wife assault are fairly lenient, is borne out by a number of studies. For example, a study of battered women in Cape Breton, Nova Scotia, found "[t]he most common outcomes were that the court issued peace bonds or put the man on probation for six months to a year. There was no pattern of sentences increasing in gravity due to repeated assaults." ${ }^{\text {"20 }}$

Similarly, the Canadian Panel on Violence Against Women states, "[s]entencing practices reveal a high level of tolerance for crimes of violence against women." 21 Leniency in sentencing seems to be related to the fact that some judges see the assault for which the man is charged as an isolated incident - one uncharacteristic episode by an otherwise "good" man - rather than as part of continued and often escalating violence. In the 1991 inquiry into police response to wife assault in Prince Edward Island, the author, himself a judge, speaks of the need for

the courts [to] be cognizant of, and have regard for the fact that, in virtually every instance, the charge of assault arising out of wife beating is merely the culmination of an ongoing situation, rather than an

17 For recommendations as to how Crown prosecutors could incorporate the experience of women, see M.L. Gaudet \& P.E. Pasquali, "As if Victims Mattered: A Guide to the More Rational Prosecutions of Men Who Violate Women and Children" (1992) [unpublished]. 
isolated incident, and accordingly, background information is significantly important in determining the appropriate disposition. ${ }^{22}$

Finally, delays caused by an overloaded court system appear to be a major problem. One assaulted woman said that the longer the period between the laying of the charge and the trial, the longer the batterer has to "work on" the woman to pressure her to abandon the case. The woman may also be in physical danger during this time, unless the man is kept in custody, which rarely happens.

\section{A MORE EFFECTIVE RESPONSE}

How should the criminal justice system respond to wife assault? The goals can be stated fairly simply:

(1) An adequate legal response to wife assault would significantly reduce the incidence of wife assault in our society and would provide immediate and long-term protection for battered women and their children.

(2) Battered women, particularly those who are now marginalized because of race, language, disability or economic circumstances, would have greater access to the legal system.

(3) Those working within the legal system would treat all battered women with respect, and would recognize that the effects of the violence are not only visible physical injuries, but also pain, fear, humiliation and a profound loss of control over one's life.

(4) Delays would be minimized.

I am not optimistic enough to think that these goals will ever be fully achieved; therefore the question becomes whether it is realistic to expect significant improvement. In her text, Feminism and the Power of Law, ${ }^{23}$ Carol Smart contends that feminists should not look to the law for social change. She holds that the "law is so deaf to core concerns of feminism that feminists should be extremely cautious of how and whether they resort to law." ${ }^{24}$ Similarly, Mary-Lou Fassel asks, "Are we being logical in believing that the patriarchal criminal law system can be made to redress women's inequality, or to end the violation of our physical and psychological integrity?"25

I agree completely with those commentators who point out that the development of the law has not been neutral with regard to issues of gender; however, the question of whether or not to use the law may be an academic debate that women experiencing violence cannot afford. "[We] currently lack both the tools and the shared vision that 
are necessary to engineer drastic social change, ${ }^{126}$ and until major social changes occur, the legal system, flawed as it is, may represent the only possibility of protection for some battered women and their children. To abandon efforts to improve the legal response would be to abandon those battered women who turn to the legal system for assistance. Furthermore, despite my bleak assessment of the way in which the criminal justice system deals with wife assault, it is also important to note that even one individual in a position of power can make a significant difference. I will give two examples from my consultations in Nova Scotia.

In one community, a new police chief took the problem of wife assault very seriously and established a good working relationship with the local transition house. Whether or not the attitudes of individual officers had undergone significant changes was to some extent irrelevant. The police chief made it clear that calls from battered women were to be made a priority, the seriousness of the situation was to be recognized, and battered women were to be treated with respect and understanding. This had an immediate impact on women's lives. More battered women were willing to turn to the police for help and those who did received significantly more protection than in the past.

My second example is of a court administrator and justice of the peace who decided to provide a one-person support service for battered women going through his court; to educate judges and court intake workers, whether they were initially receptive or not, about the realities of wife assault; and to "put the fear of God" into male batterers who appeared before him to sign peace bonds. I was told that this was making a real difference, that battered women were beginning to see the court in which he worked as far more accessible and more likely to respond sensitively to their situation.

In the last few years, a number of reports have made quite detailed recommendations as to how to improve the response of the criminal justice system to wife assault. ${ }^{27}$ It is not my intention to repeat those recommendations here, although I think a number of the recommendations are implicit in my criticism of the way in which the criminal law is presently enforced and in my description of how the criminal justice system should respond to wife assault. My focus here is on a number of general themes, rather than on detailed recommendations.

First, it is important to avoid the easy solution of merely "reforming the reform."28 Therefore, the attempt to improve the way in which the police and the courts deal with wife assault must be placed in its proper context. Violence against women, imbedded as it is in the imbalance of power between men and women, will not be eliminated until there is a fundamental societal shift toward full equality for women. Therefore, it is 
important to focus not only on changes in the enforcement of the criminal law but also on broader measures directed at changing the position of women in society. ${ }^{29}$

Secondly, the myths and stereotypes I referred to earlier must be confronted directly. As long as women are seen as deserving or enjoying violence, wife assault will continue to be tolerated. If the criminal law is to have any real impact on the incidence of wife assault, it must be made clear to police, Crown prosecutors and others in the legal system that dealing with wife assault is a top priority. This would seem to require a two-part approach: education and sanctions. A constant theme during my consultations in Nova Scotia was the need for mandatory education on the realities of wife assault for all individuals working within the justice system. Similarly, the Canadian Panel on Violence Against Women states that "[o]ne important step [toward creating a knowledgeable judiciary] is mandatory judicial training. The training must challenge all long-standing prejudices and ideologies around issues of gender, race and class inequality in Canada." ${ }^{30}$

This comment would seem to apply not just to judges but to all those within the criminal justice system who come into contact with battered women. Police officers, lawyers and judges also need training on the practical points that could provide increased protection for women, for instance: the wording of the arrest powers; the range of conditions that can be attached to a peace bond; the fact that the courts can require a batterer to stay away from his wife while the case makes its way through the system; the use of victim impact statements; and so forth.

Clearly, education is important, but it is not enough. There must be sanctions for those who continue to treat wife assault cases as a low priority or who continue to treat battered women with insensitivity and disrespect. To put it bluntly, poor handling of these cases must start impeding career opportunities, and, conversely, appropriate handling of wife assault cases should enhance career opportunities. The Canadian Panel on Violence Against Women recommends the appointment of police commissioners, judges, and others who have "demonstrated understanding of equality issues and the complex dynamics of violence against women." ${ }^{31}$ Presumably, this would serve two purposes: it would provide a tangible reward for those who have dealt with the issue appropriately, and would try to ensure that those in a position to affect the workings of the criminal justice system are aware of how violence affects women's lives. As I mentioned earlier, the attitude of one police chief made a significant difference, whatever the attitudes of the officers under him.

\section{CONCLUSION}

Obviously, there are many other specific ways in which the criminal justice system needs to reform itself in order to deal more appropriately, sensitively and effectively 
with wife assault, and these are detailed in the numerous reports referred to earlier. Of course, no system will simply reform itself. There are individual police officers, lawyers, judges, probation officers and others who do take wife assault very seriously, and this is reflected in their handling of wife assault cases. Thus far, however, there does not seem to have been any significant organized attempt within the criminal justice system itself to confront the fact that the system has failed battered women. Criticism has usually come either from battered women and their advocates; that is, from voices which have not traditionally held much influence within the legal system, or from government in the form of sponsored reports, which, while gathering a great deal of pertinent information and making useful recommendations, often are not translated into real changes.

Change, if it occurs at all, will come about only as a result of concerted efforts by those both within and outside of the justice system. This brings me back to the conference theme of "professional responsibility." Trying to prod the law into taking wife assault seriously is a daunting task; however, I believe that we, as lawyers, must do that prodding, as loudly and as persistently as possible. This is our collective professional responsibility. 